ارزيابى تأثير برخى عوامل محيطى بر ميزان انحلال گج در خاكهاى گجِى

\author{
نادر عباسى '* و على عباس افشاريانج

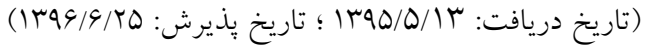

جكيده

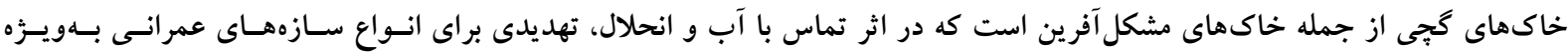

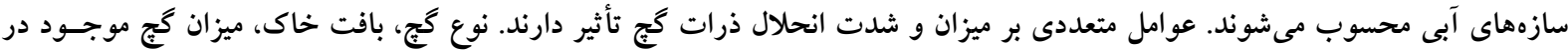

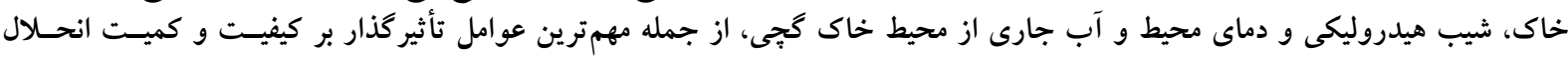

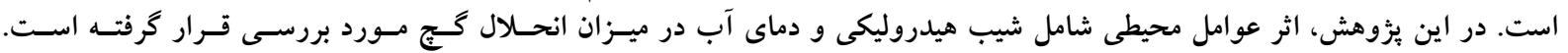

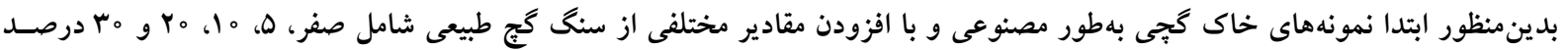

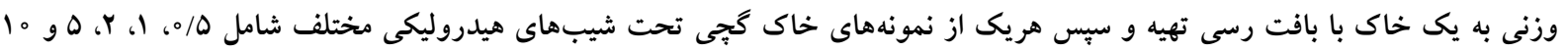

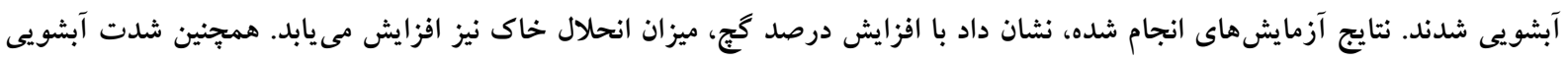

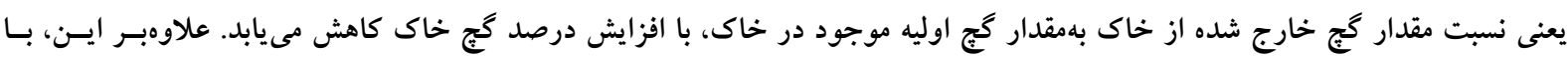

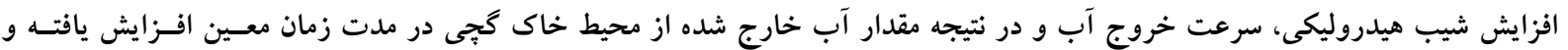

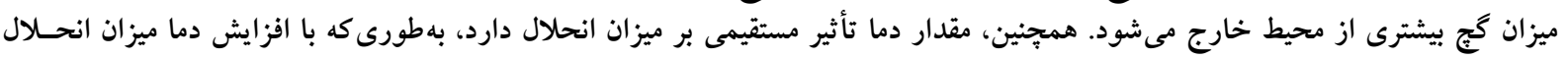

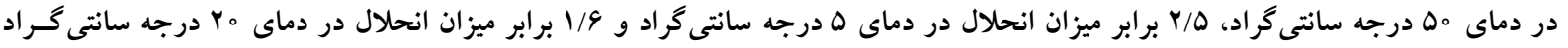

وازههاى كليدى: خاك گجِى، سرعت انحلال، شيب هيدروليكى و دما

\footnotetext{
1. مؤسسه تحقيقات فنى و مهندسى كشاورزى، سازمان تحقيقات، آموزش و ترويج كشاورزى، كرج آنان r. شركت سهامى آب و فاضلاب، استان ايلام

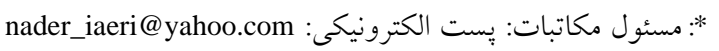


كَ موجود در خاك در اثر تماس بـا آب و انحـلال، همـراه بـا

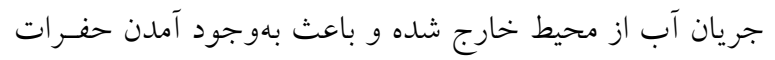

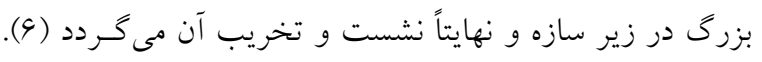
در دهلهاى اخير تخريب سازههاى استقرار يافته روى خاكهاى

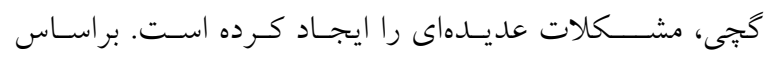

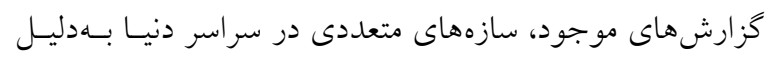

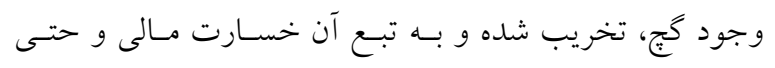

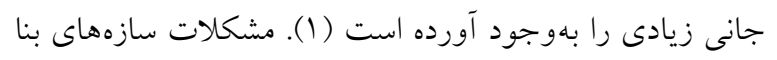
شده روى زمينهاى گجىى، اولين بار در سـال 19TV در اسـهانيا

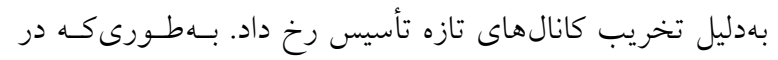

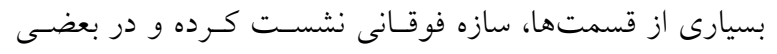

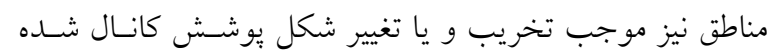
است. شكست سد سنت فرانسيس در ايالت كاليفرنيـاى آمريكـا

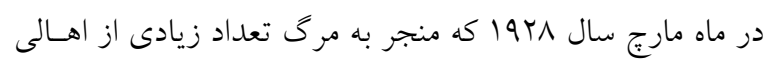

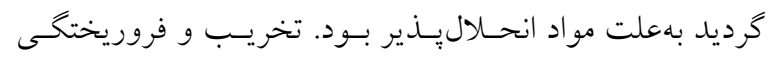
كانالهاى سلهابيه در حوضه رودخانه فرات در كشـور سـوريه،

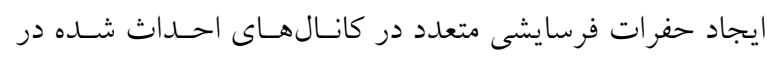
منطقه مادريد در كشور اسپانيا، از جمله مواردى هستند كه علت

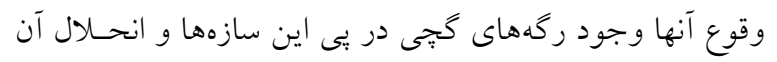

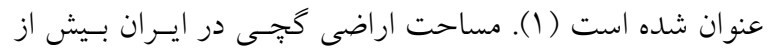

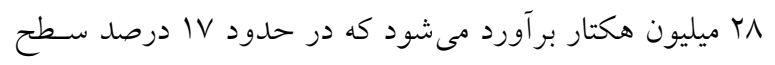

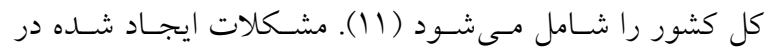

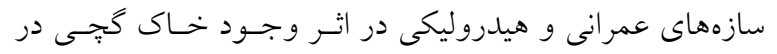

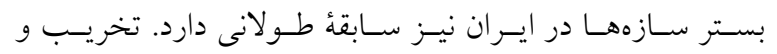

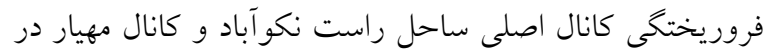
حوضه رودخانه زاينده رود در اصفهان از بارزترين مثـالهـا در خصوص تخريب كانال در اثر وجود خاك گيى در بستر كانال

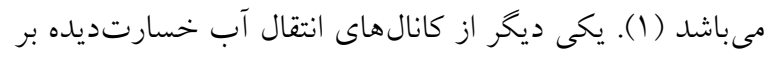

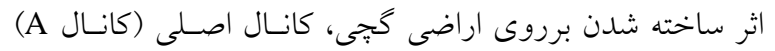

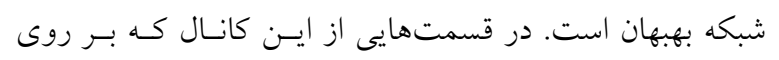

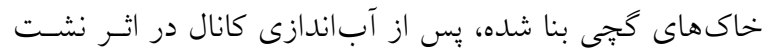

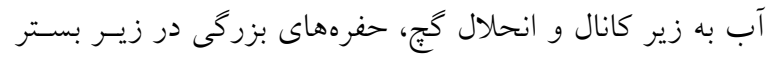

\section{مقلمه}

احداث شبكههاى آبيارى و زهكشى در اراضى بايـاب سـدهاى

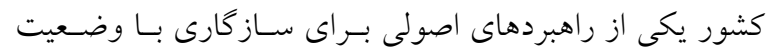

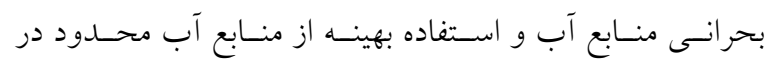
دسترس مىباشد. در اين راستا، تاكنون بيش از ب ميليون هكتـار

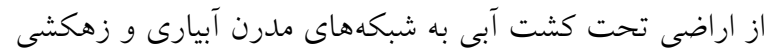

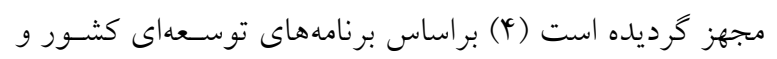

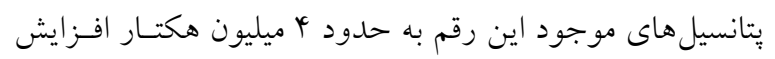

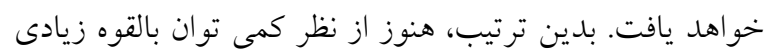

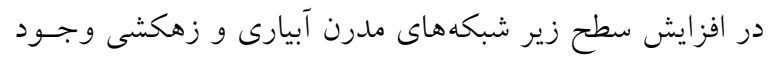

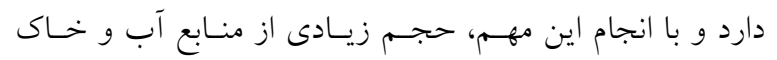

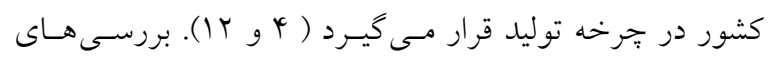

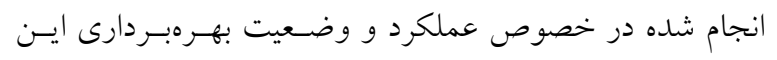

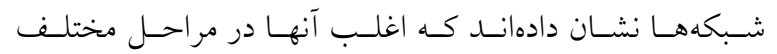

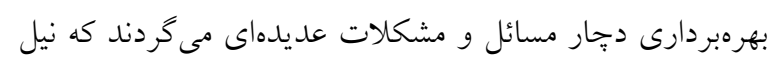

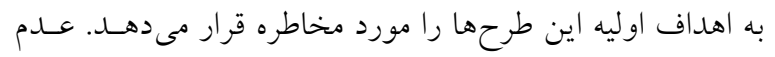

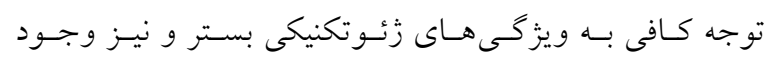

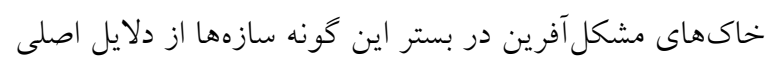

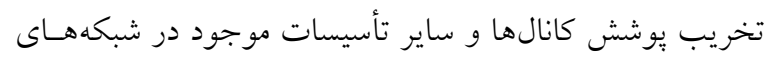

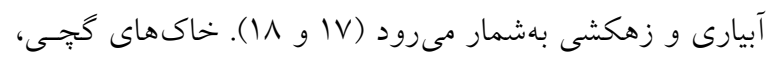

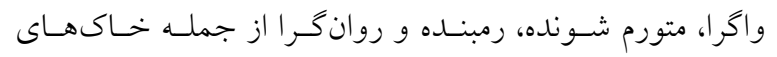

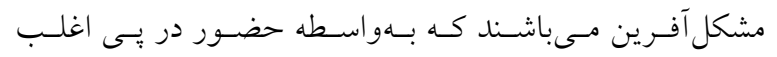

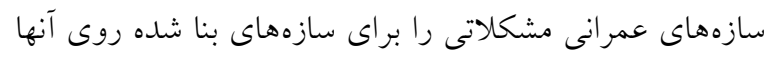

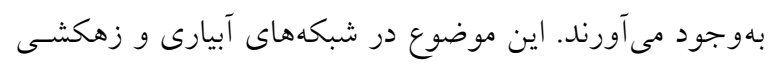

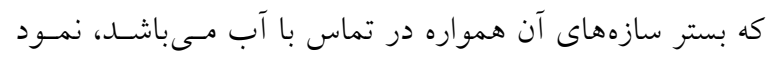

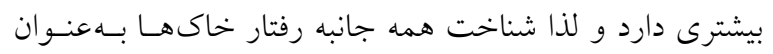

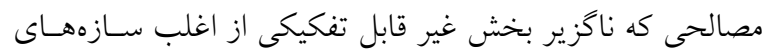

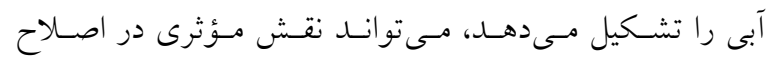

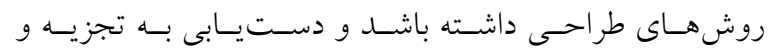

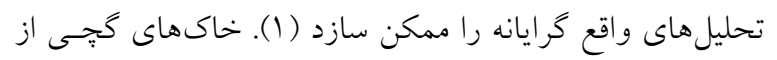

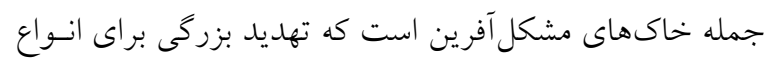

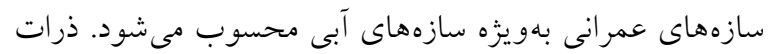


باعث افزايش ميزان حلاليت گج مىشود، بهطـورىكـه حـــاكثر

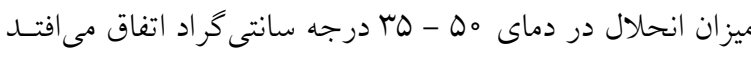

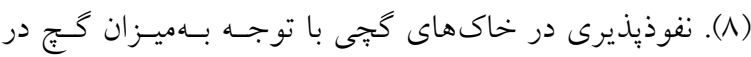

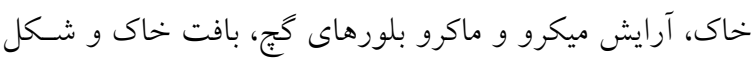

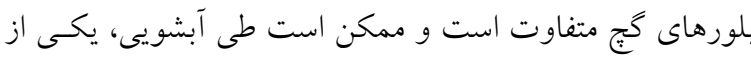

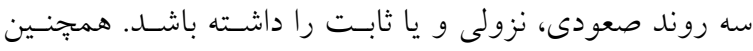

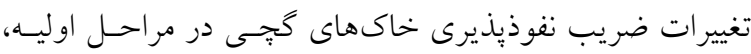
بهدليل حركت ذرات خاك و شسته شدن گَج نسبتاً زياد بوده اما

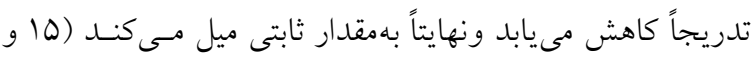

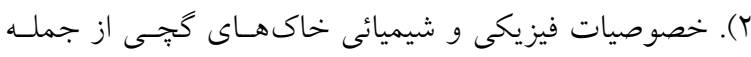

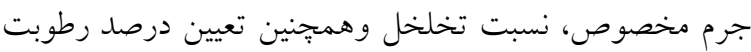

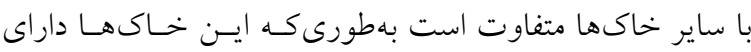
جرم مخصوص حقيقى كمترى نسبت به خاكهاى مشابه بوده و

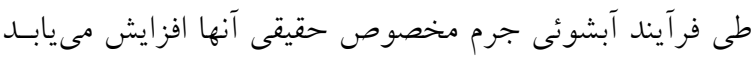

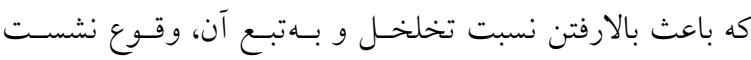

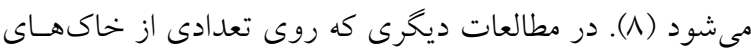

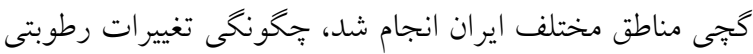

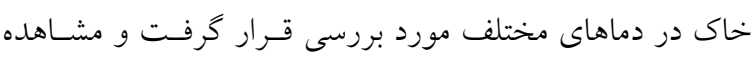

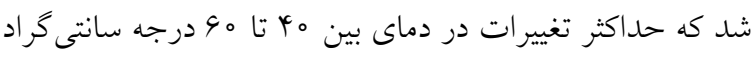

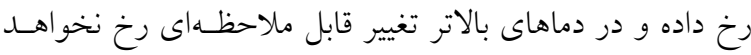

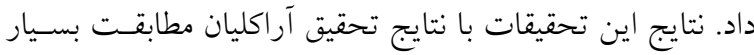
نزديكى دارد (4 (). عليرغم وجود سطح وسيعى از اراضى كَّى

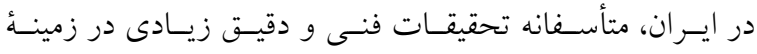
مشخصات زئوتكنيكى و مسائل و مشكلات ناشى از وجود گَج

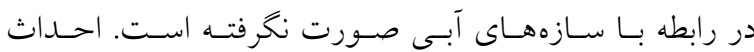

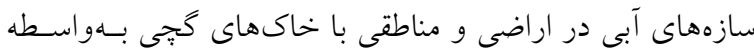

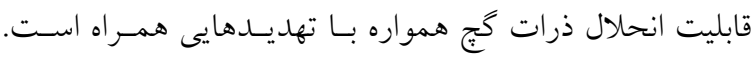

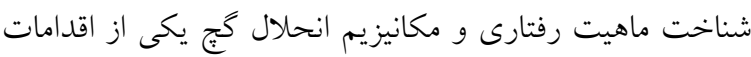

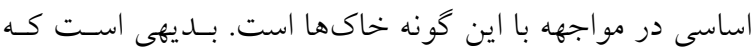

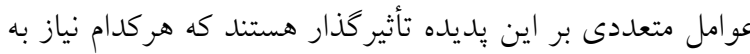

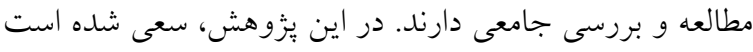

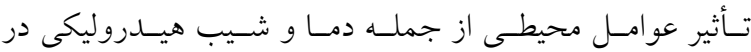

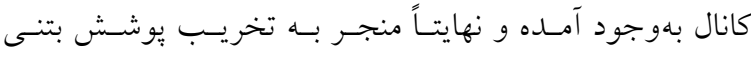
كرديده است (ه). تخريب كلى كانال و آبشستكى مسـير كانـال

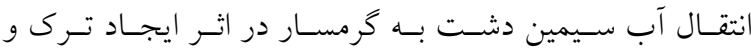

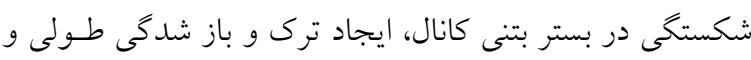
عرضى در خاكريزها بهواسطه وجود سازندهاى نامقاوم گجيى -

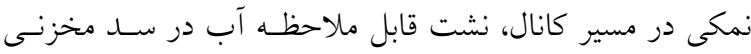

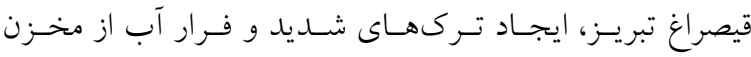

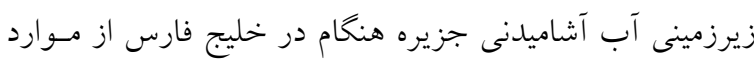

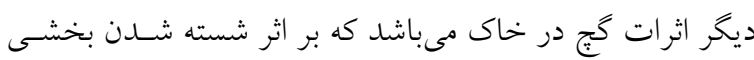

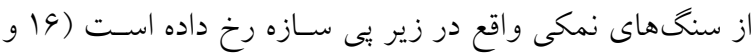

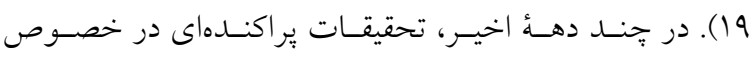

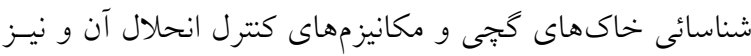

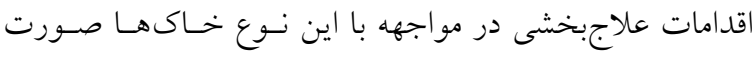

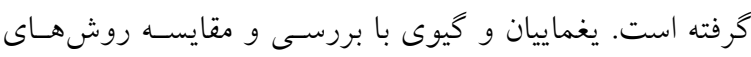

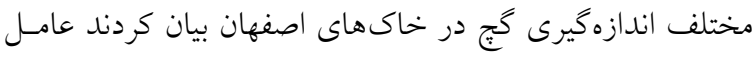

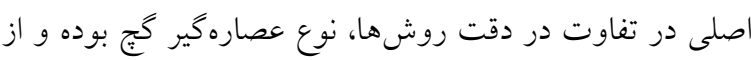

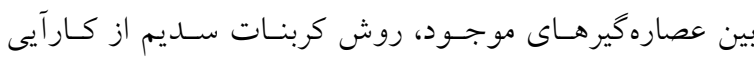

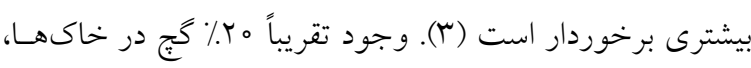

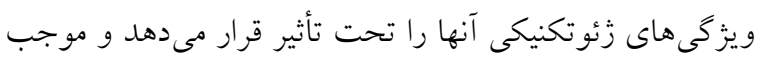

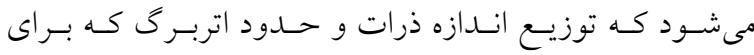
طبقهبندى خاكها استفاده مىشود، مقادير واقعى خــود را نشـان

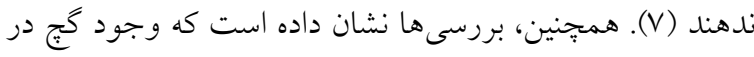

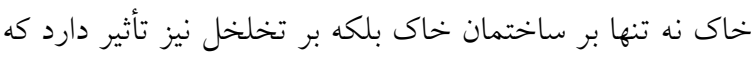

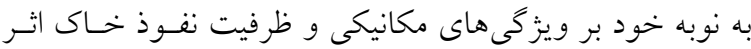

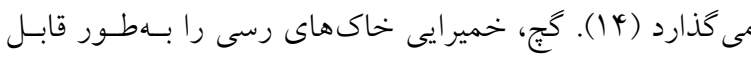

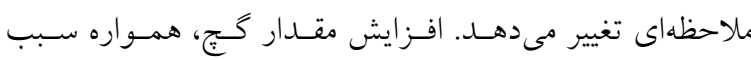

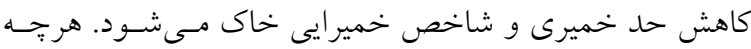

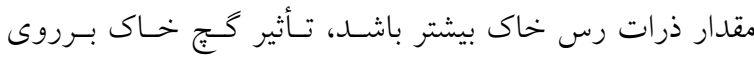

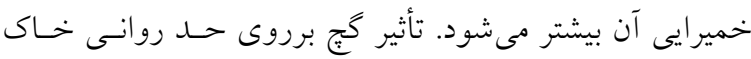

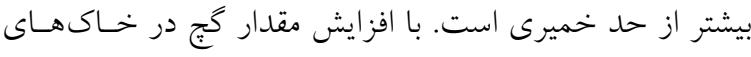

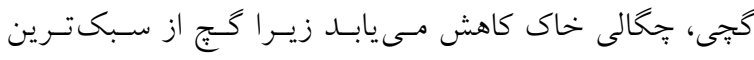

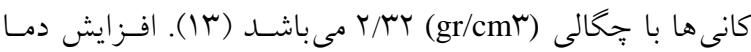


نشر يه علوم آب و خاك (علوم و فنون كشاورزى و منابع طبيعى) / سال بيست و دو / شماره يك/ بهار IYV

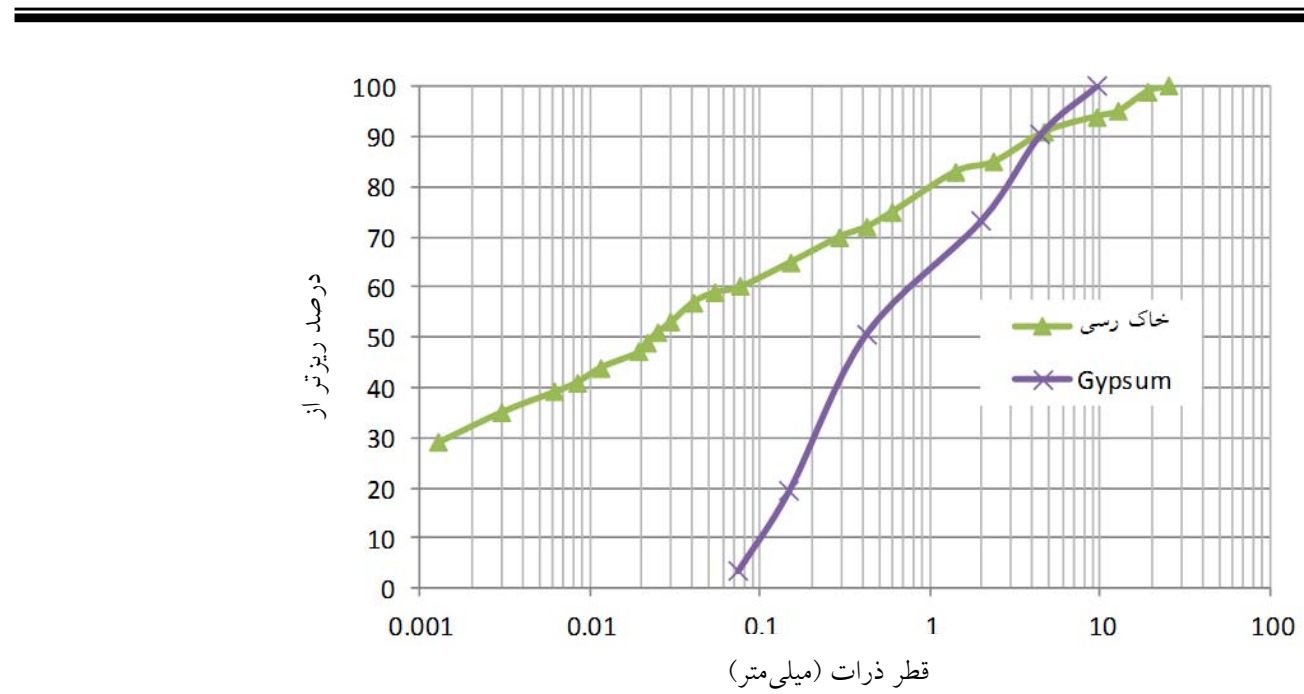

شكل 1. منحنى تجمعى دانهبندى نمونهاى مورد بررسى درى

جدول ا. مشخصات فيزيكى خاك مورد بررسى

\begin{tabular}{|c|c|c|c|c|c|c|c|}
\hline \multirow{2}{*}{$\begin{array}{l}\text { طبقهبندى (يونيفايد) } \\
\text { (ينايد }\end{array}$} & \multicolumn{2}{|c|}{ حدود آتربرى (درصد) } & \multicolumn{2}{|c|}{ (آزمايش مشر اكتور استاندارد) } & \multicolumn{3}{|c|}{ بافت (\%) } \\
\hline & خميرى & حد روانى & ماكزيمم وزن واحد حجم & رطوبت بهينه & شن و ماسه & سيلت & رس \\
\hline $\mathrm{CH}$ & سח & 90 & $1 / 91$ & IV & yr & rq & ro \\
\hline
\end{tabular}

جدول r. نتايج آناليز شيميايى نمونه مورد بررسى

\begin{tabular}{|c|c|c|c|c|c|c|c|c|c|c|}
\hline \multirow{2}{*}{ كاتيونها } & \multicolumn{3}{|c|}{ كاتيونها (meq/lit) } & \multirow{2}{*}{ آنيونها } & \multicolumn{4}{|c|}{ آنيونها (meq/lit) } & \multirow{2}{*}{$\begin{array}{c}\text { EC } \\
(\mathrm{dS} / \mathrm{m})\end{array}$} & \multirow{2}{*}{$\mathrm{pH}$} \\
\hline & $\mathrm{K}^{+}$ & $\mathrm{Na}^{+}$ & $\mathrm{Mg}^{+r}+\mathrm{Ca}^{+r}$ & & $\mathrm{SO}_{\psi}{ }^{-r}$ & $\mathrm{Cl}^{-}$ & $\mathrm{HCO}_{r}{ }^{-}$ & $\mathrm{CO}_{r}{ }^{-r}$ & & \\
\hline TMY/A & ro & $.1 \mathrm{VV}$ & TY/A & $r Y q / D$ & $9 T / 0$ & $1 \wedge 0$ & r & - & r/Aץ & $V / V Q$ \\
\hline
\end{tabular}

نمونه خاكهاى طبيعى اضافه و خاى گجى با درصد معين گــج تهيه كرديد. ويزگكى هاى فيزيكى و شـيميائى خـاك هــا قبـل از

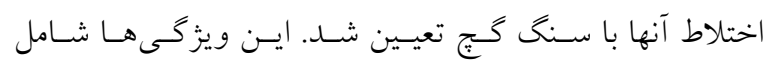

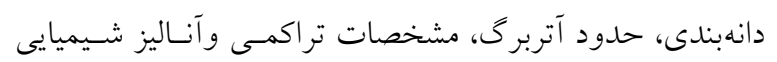
(تعيين آنيونها و كاتيونهاى مهم، تعيين pH و EC) مسىباشـد. منحنى دانهبندى نمونه خاك و كـج مـورد اسـتفاده بـراى تهيـهـ نمونههاى خاى كجىى در شـكل (1) و مشخصـات فيزيكى و شيميائى نمونه خاك به ترتيب در جـدولهــاى (1) و (Y) ارائسه
انحلاليذيرى نمونههاى خاى با بافت رسى بررسى گردد.

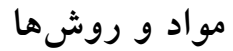
مشخصات نمونه ماى خاى نمونههاى خاى مورد بررسى از اراضى مهران استان ايـلام تهيـهـ كرديده است. در اين يزوهش، نمونه خاكهاى گجى، با افزودن

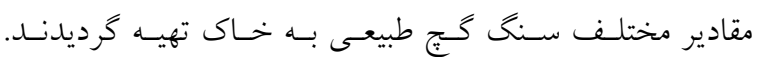
بدينمنظور، سنخ گَج يس از خرد شدن در مقادير مختلـف بـه 


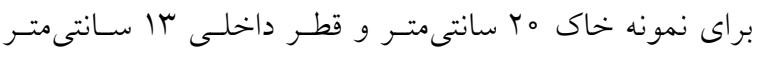

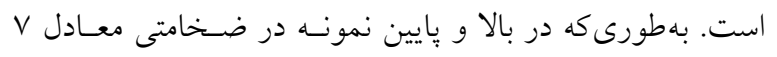

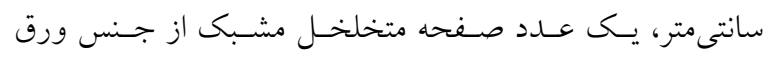

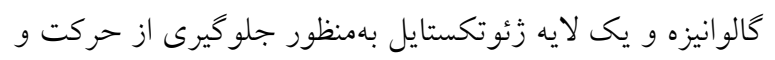

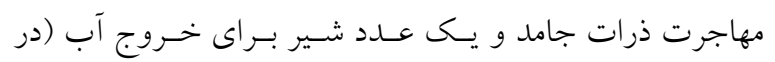

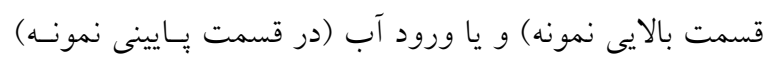

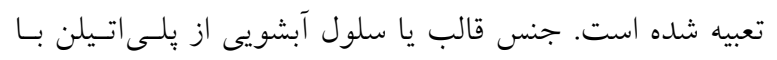

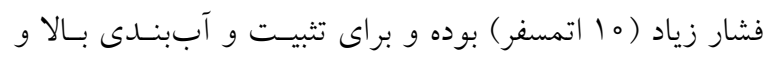

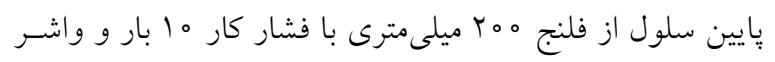

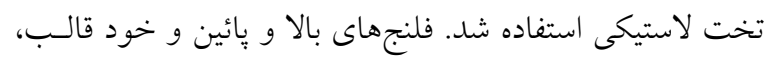

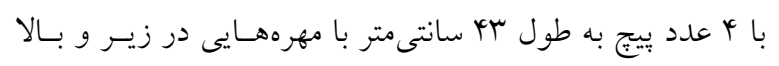

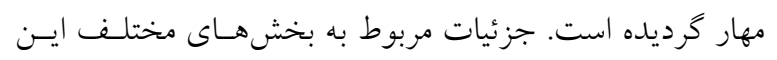

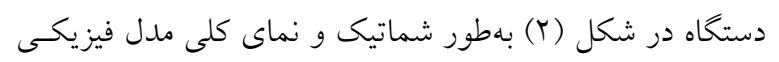

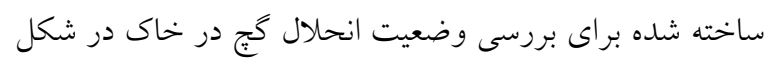
(r) نشان داده شده است. همانطوركه در شكل هاى بالا مشاهده شد، بـر ایى ايجـاد بـار

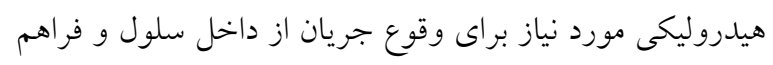

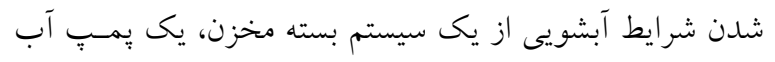

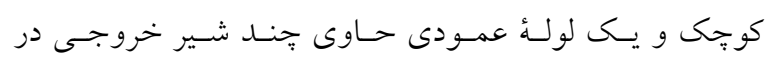
ارتفاعهاى مختلف استفاده كرديد. بدين ترتيب كه آب از از داخل

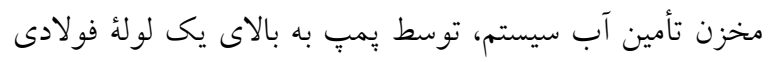

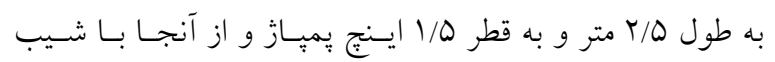

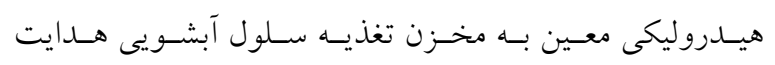

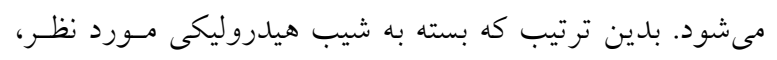

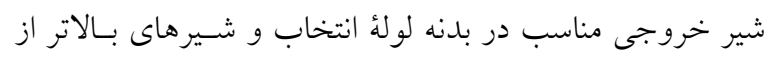

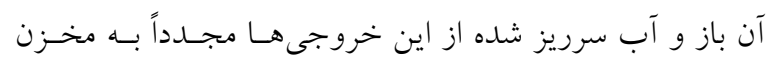

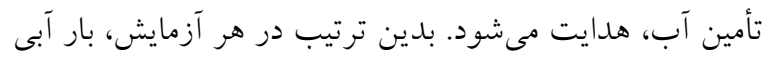

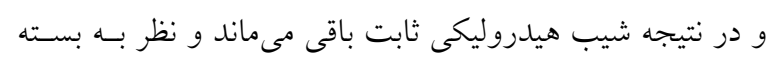

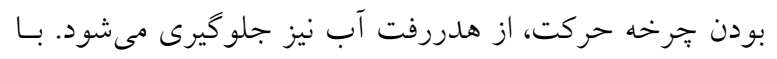

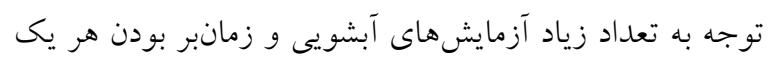

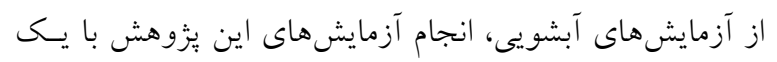

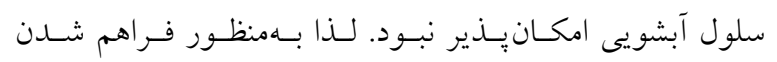

كرديدهاند. با توجه به اينكه براى متراكم كردن نمونسه خـاكهـا

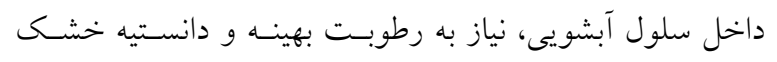

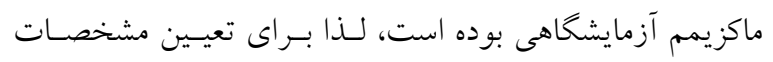

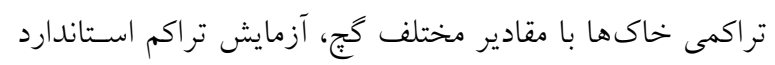

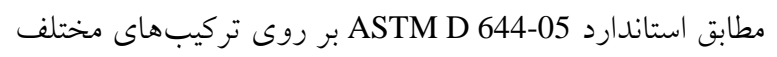

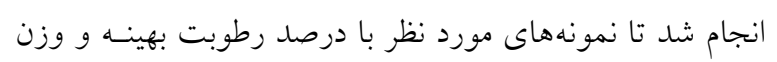

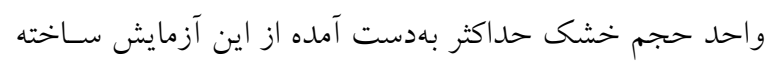

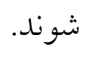

\section{معرفى تيمارها}

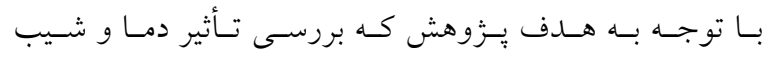

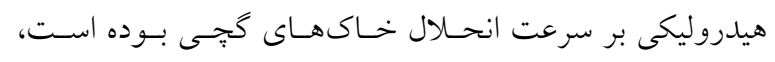

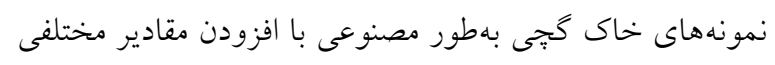

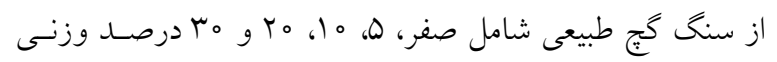

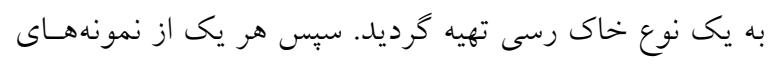

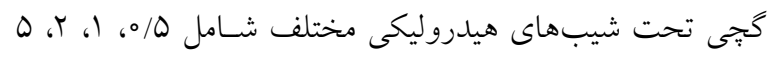

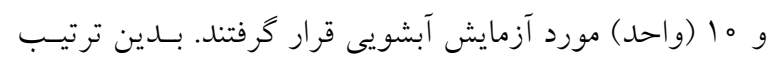

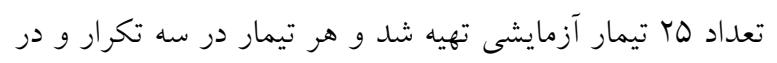
كل Va آزمايش آبشويى انجام كرفت.

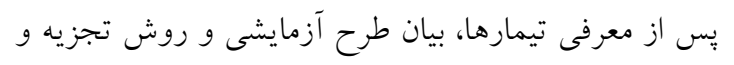
تحليل آمارى ضرورت دارد.

\section{معرفى مدل فيزيكى انحلال گج در خاى}

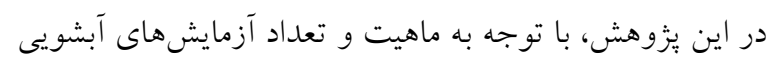

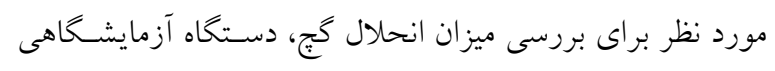

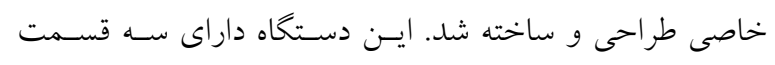

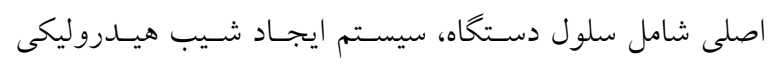

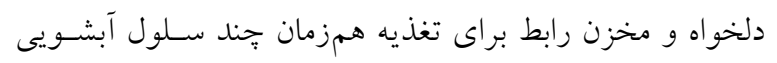

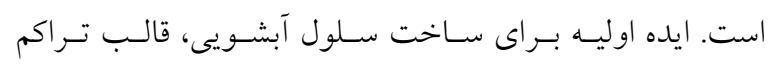

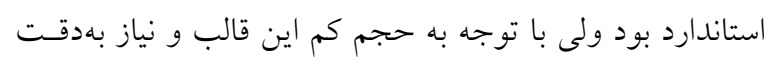

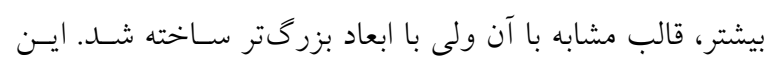

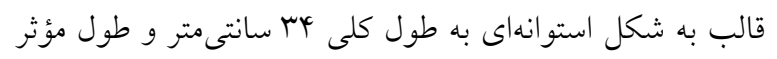



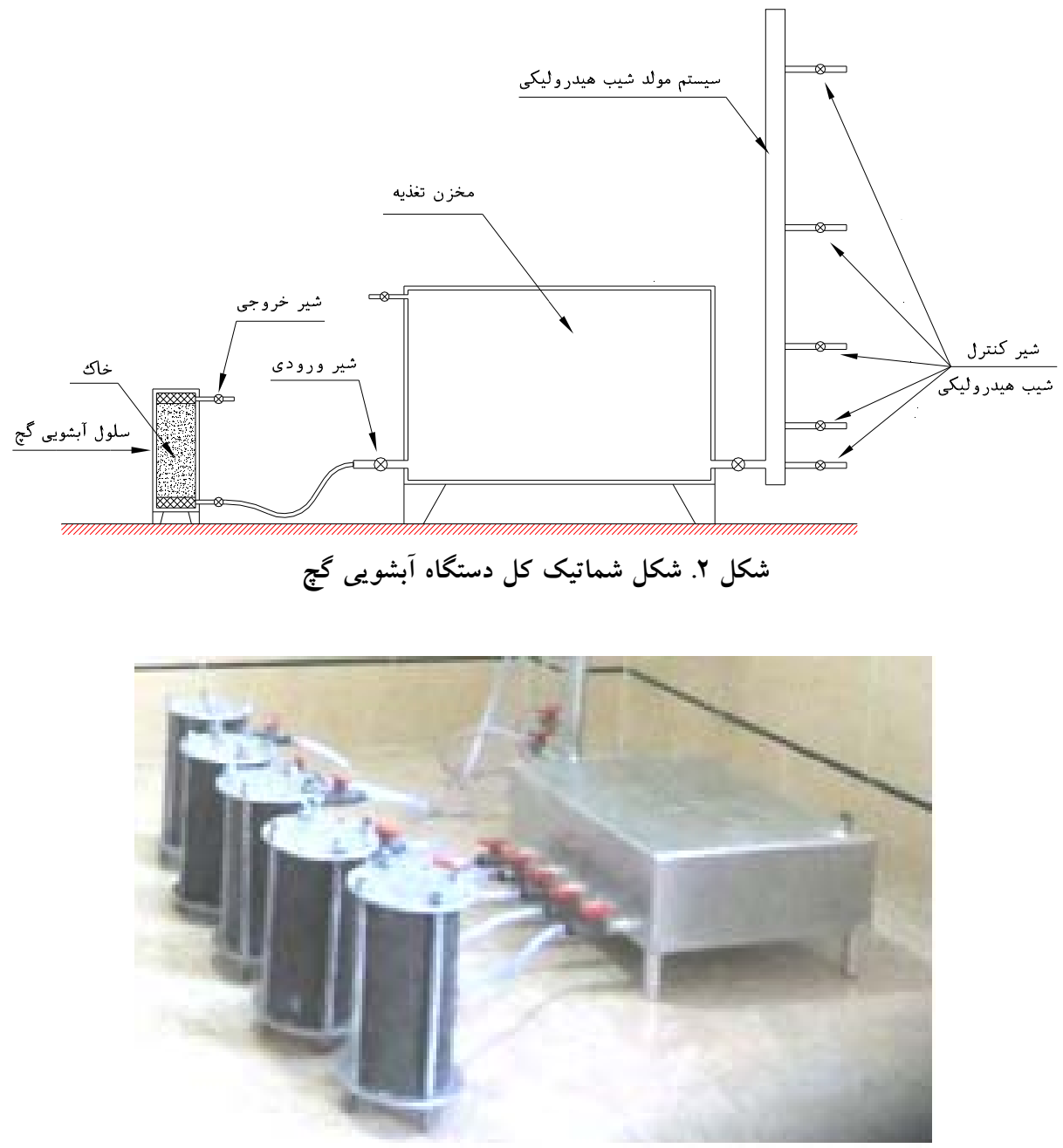

شكل r. دستكاه آبشويى گج مورد استفاده در اين برُوهش

امكان انجام همزمان جنند آزمايش آبشويى و بـه عبـارتى امكـان آبشويى تحت شيب هيدروليكى يكسان ميسر شده است.

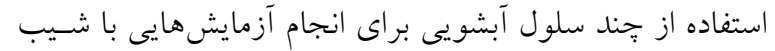

\section{تهيه نمونههاى آزمايشى خاك}

در اين يزوهش، براى ساخت نمونههاى آزمايشسى خـاك ابتـدا نمونههاى خاك كَيى بهطور مصنوعى با اضـافه كردن مقـادير

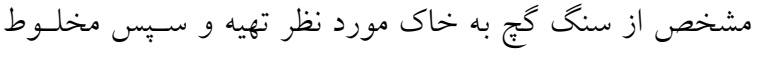

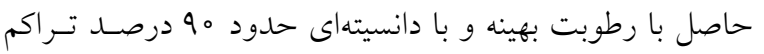
آزمايشـاهى در قالـب مخصسوص دسـتخاه آزمايشسى متــراكم

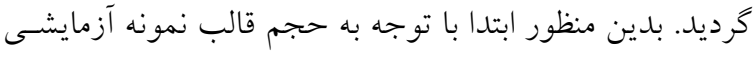

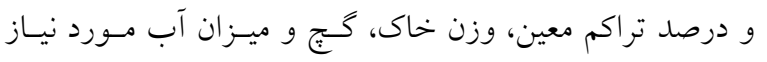

هيدروليكى يكسان، از يكى مخزن تنظيم و تغذيسه كننـده شـيب

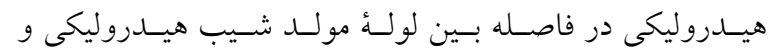

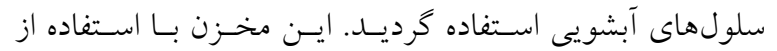

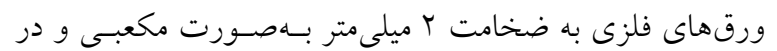

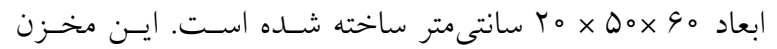

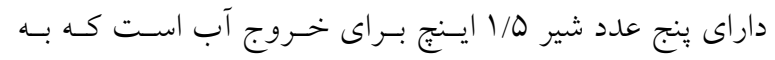

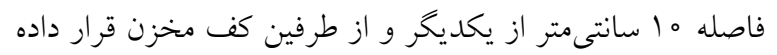

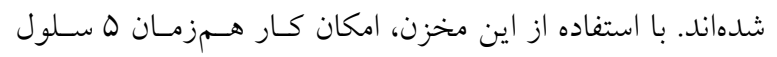


بار صاف و با آب مقطر داغ شستشو شد. محلول زير صافى بـهـ

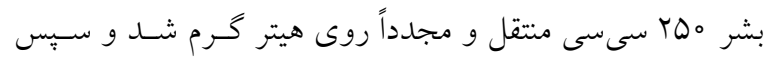

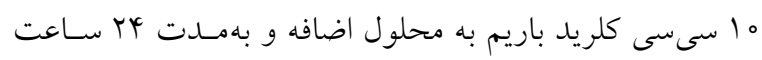

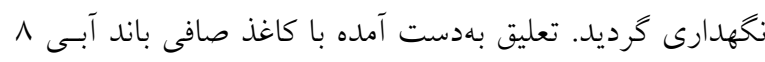

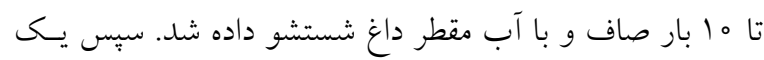

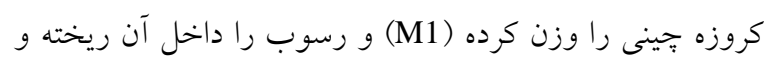

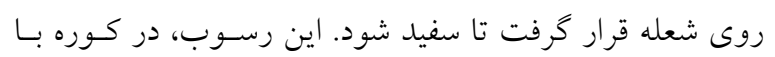

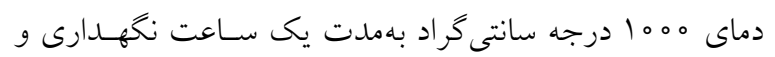

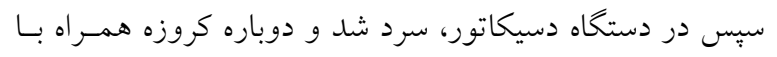

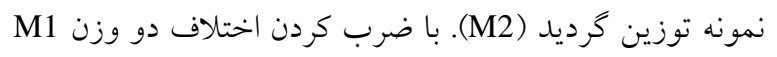

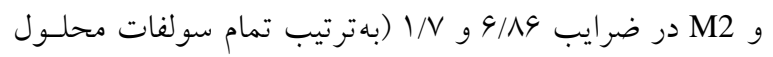

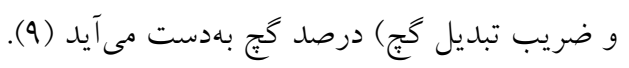

\section{نتايج و بحث}

بهمنظور تعيين مشخصـات تراكمى تيمارهـاى مـورد بررسى،

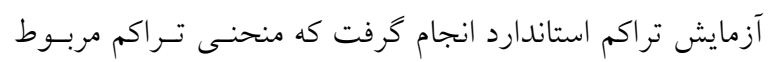

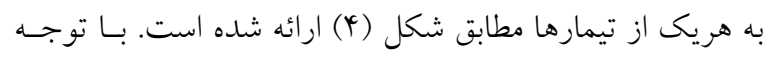

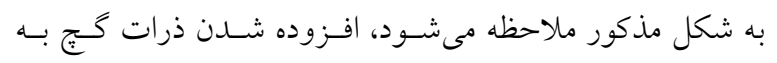

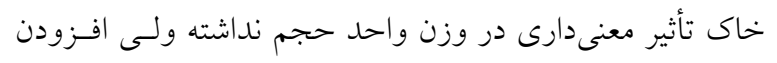

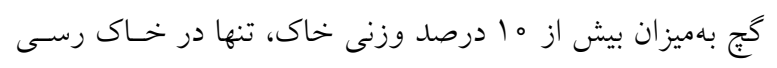

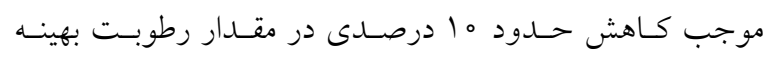

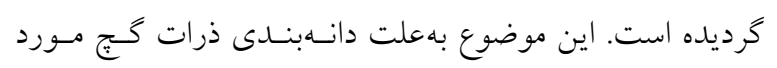

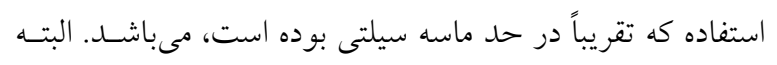

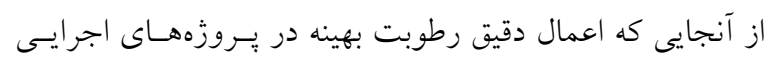

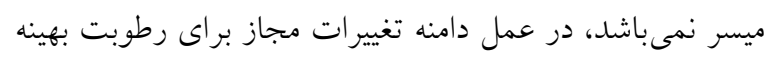

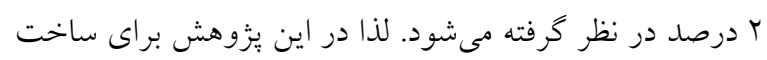

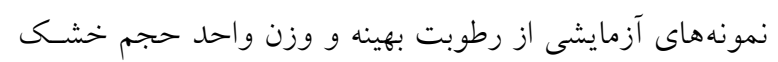
متوسط براى همه نمونه ها استفاده شد.

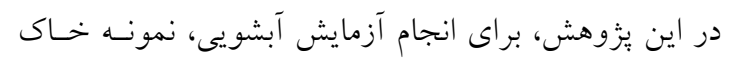

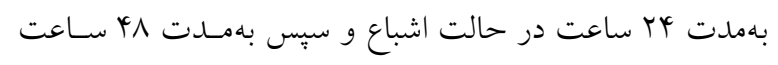

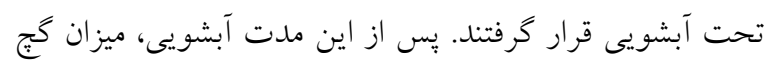

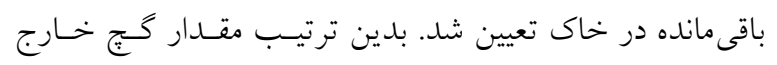

براى رساندن مخلوط خاى گجى بهميزان رطوبت بهينه مخلوط،

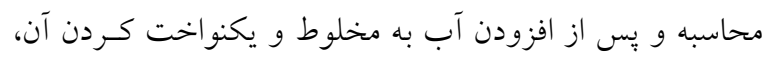

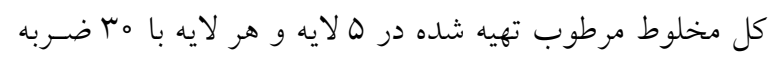

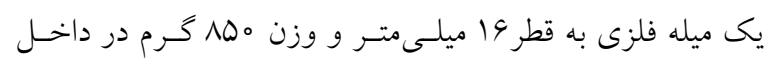

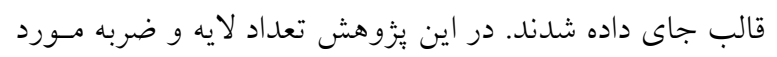

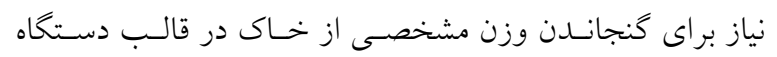
براساس سعى و خطا تعيين كرديد.

\section{آزمايش تعيين ميزان انحلال گَج}

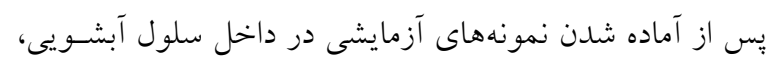

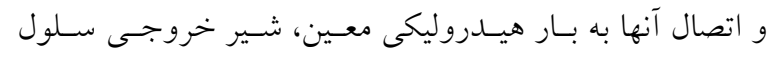

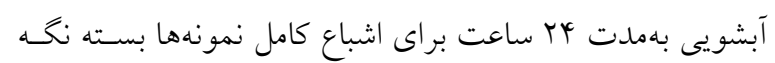

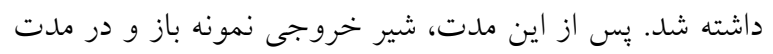

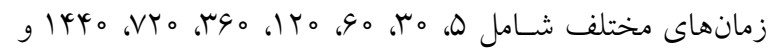

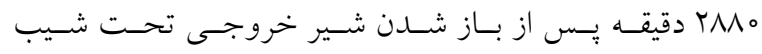

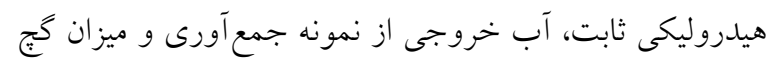

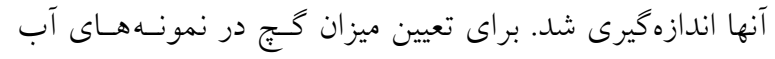

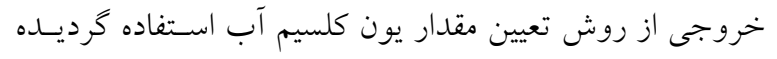

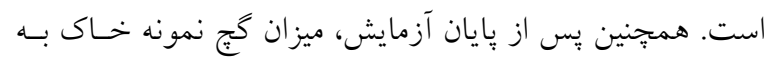

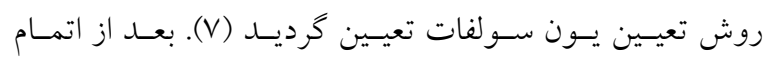

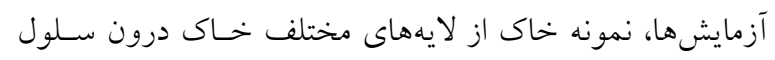

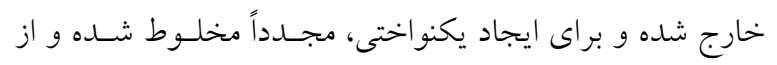

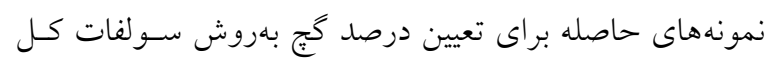

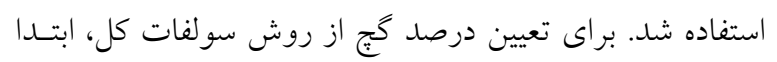

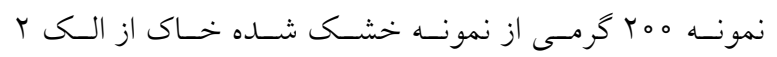

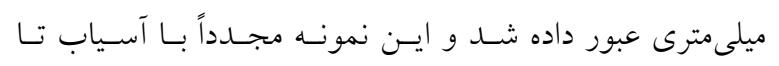

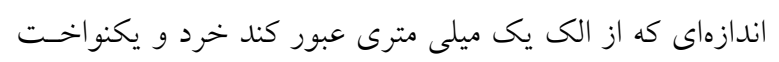

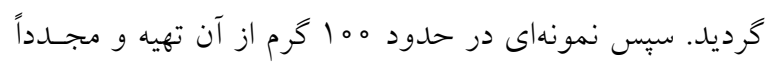

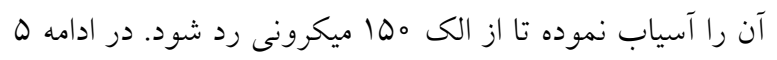

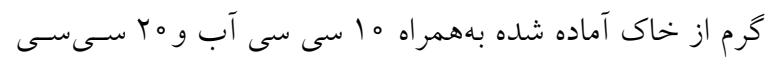

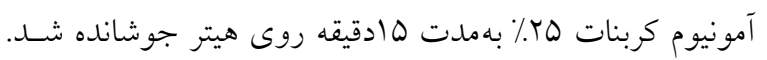

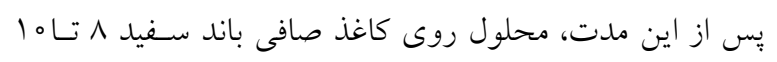


نشر يه علوم آب و خاك (علوم و فنون كثاورزى و منابع طبيعى) / سال بيست و دو / شماره يك/ بهار IraV

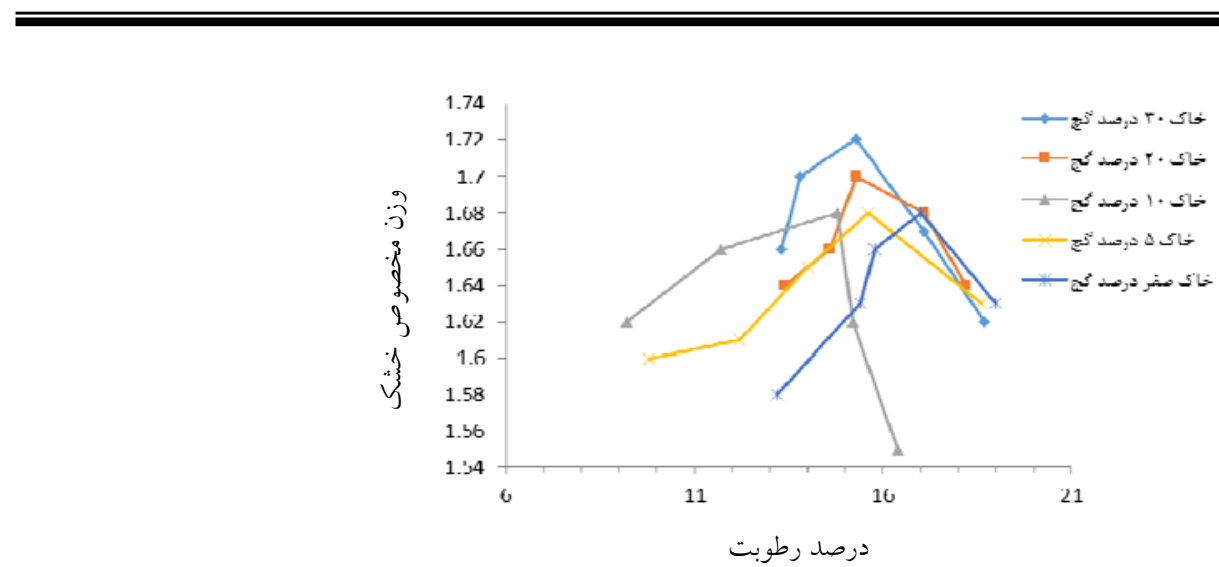

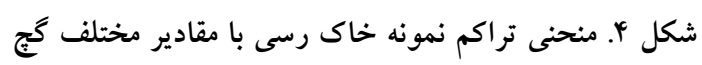
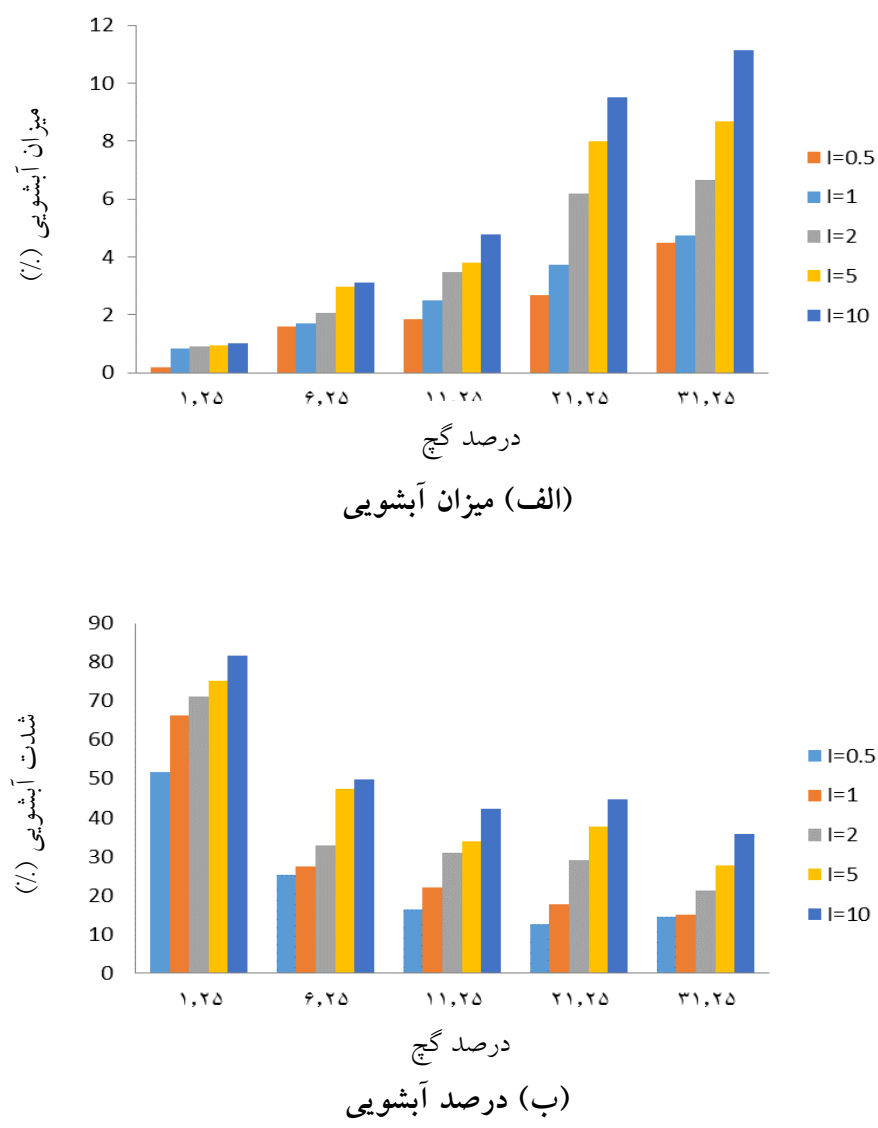

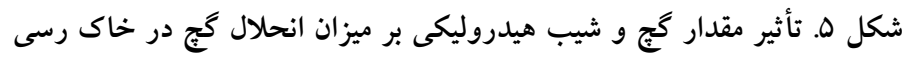

شده از هريك از تيمارها در اثر آبشويى و نرخ آبشويى در آنها توجه به شكل (ه) ملاحظه مىشود، مقدار گج موجود در خاك

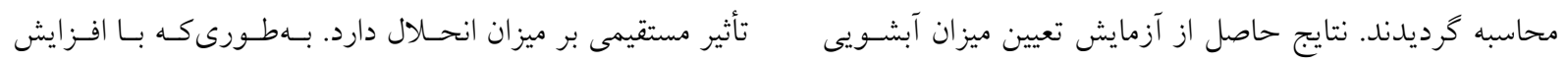

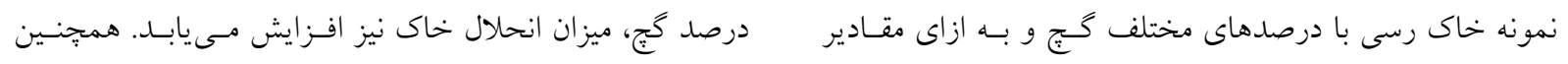

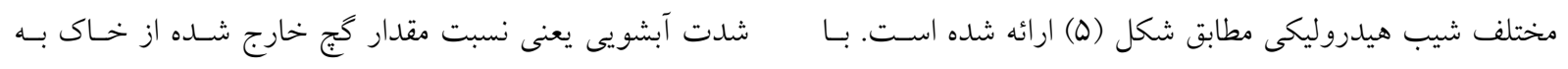




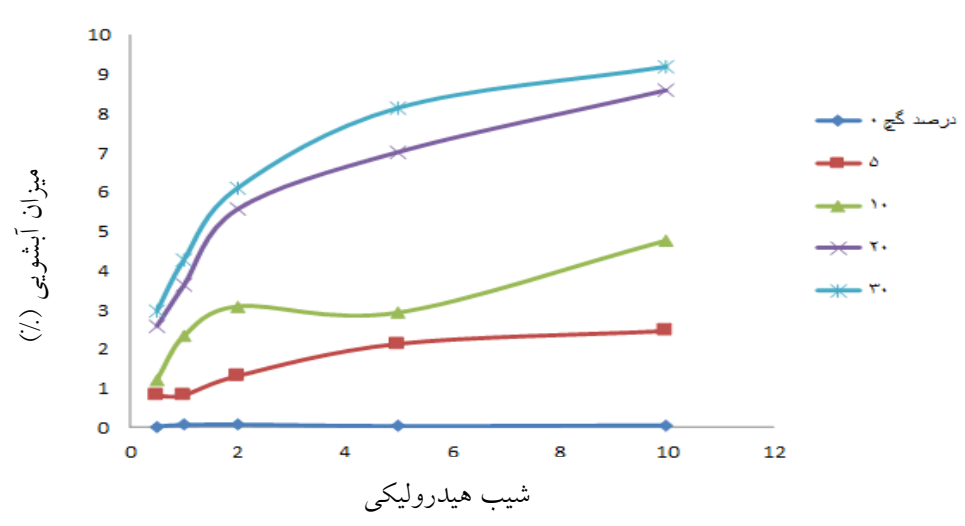

شكل צ. تأثير ميزان گج وشيب هيدروليكى بر ميزان انحلال گج در خاك رسى

بلهورى كه با دو برابر شدن شيب هيدروليكى ميـزان انحـلال نيـز تقريباً هD درصد افزايش مىيابد.

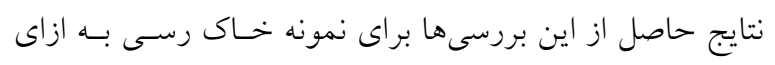

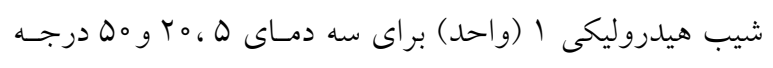

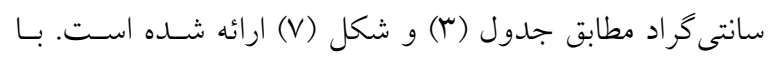

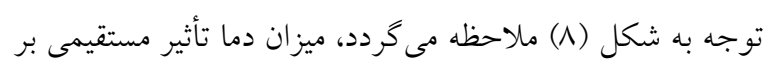

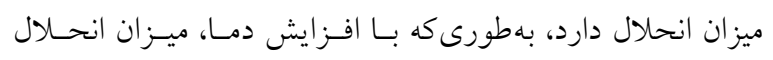

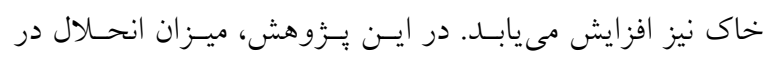

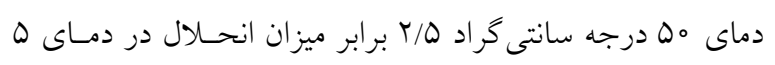

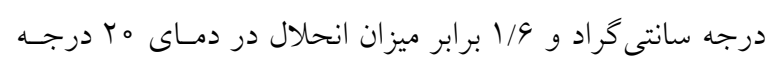

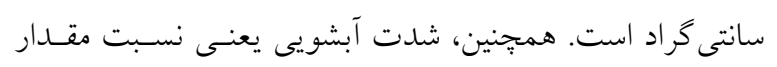

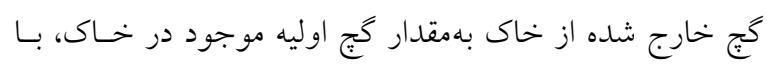
افزايش درصد گج خاك مى يابد.

\section{نتيجه گيرى}

در اين يزوهش اثر سه عامل درصد گجه، شيب هيدروليكى و دما

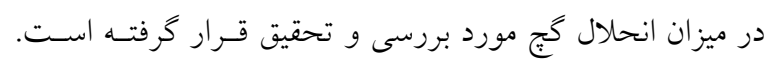

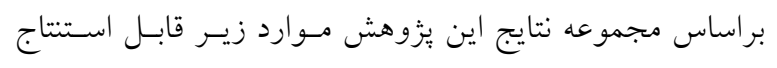

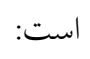

1. گَج موجود در خاك تأثير مستقيمى بر ميـزان انحـلال دارد.

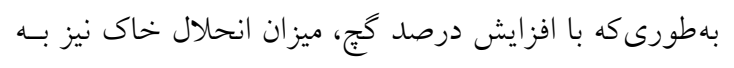
همان ميزان افزايش مىيابد.

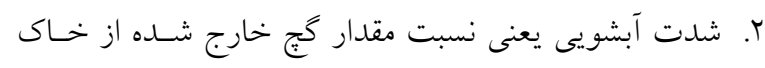

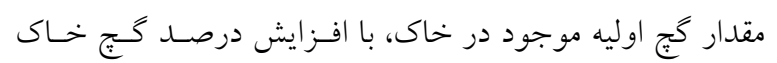

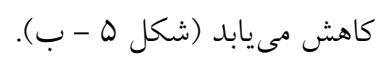

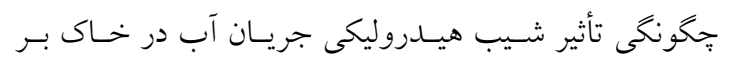

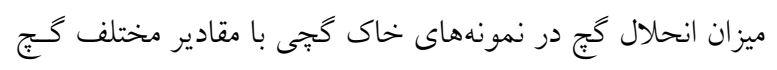

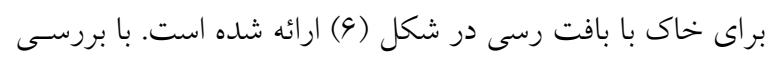

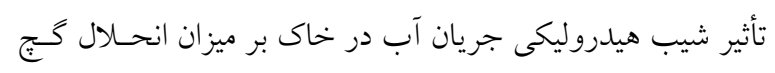

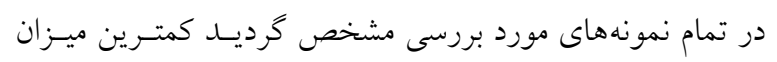

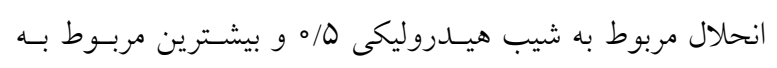

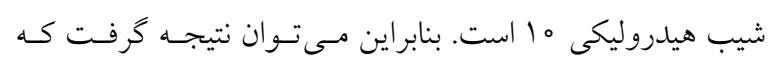

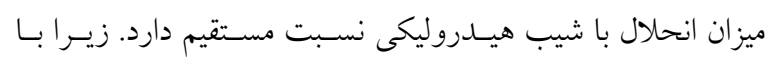
افزايش شيب هيدروليكى سرعت خــروج آب و در نتيجـه مقــدار

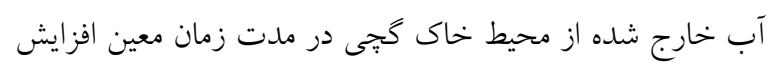

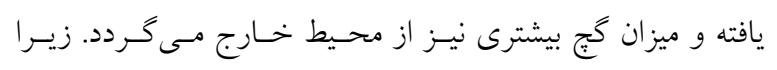

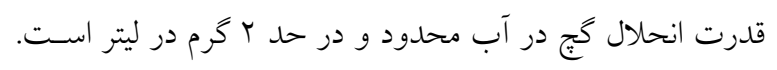

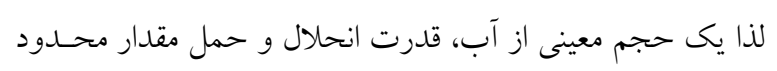

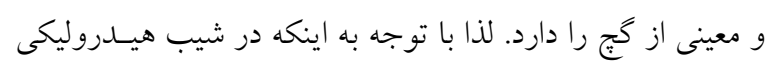

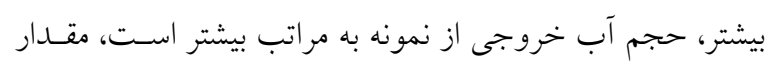

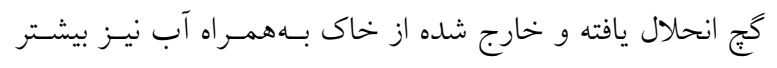

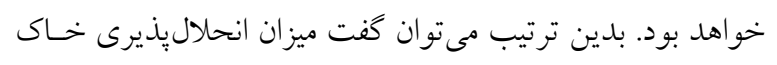

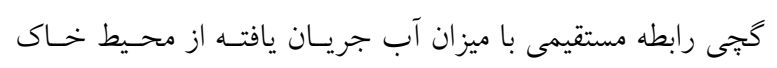

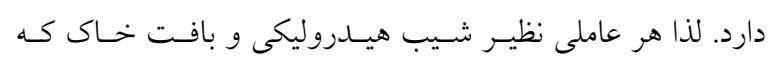

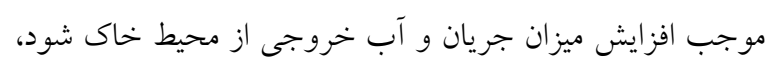

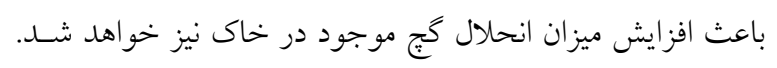


نشر يه علوم آب و خاك (علوم و فنون كشاورزى و منابع طبيعى) / سال بيست و دو / شماره يك/ بهار IrqV

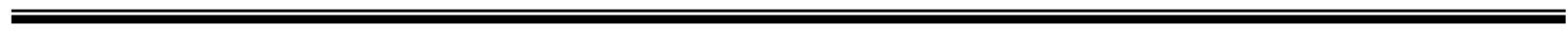

\section{جدول r. درصد آبشويى و شدت آبشويى خاك رسى در دماهاى مختلف با شيب هيدروليكى ا (واحد)}

\begin{tabular}{|c|c|c|c|c|c|}
\hline شدت آبشويى (درصد) & درصد انحلال گج & درصد گج بعد از آبشويى & درصد گج قبل از آبشويى & $\begin{array}{c}\text { (سانتى گراد) } \\
\text { (ساد) }\end{array}$ & رديف \\
\hline ky & $\circ / \Delta \Delta$ & $\circ / V$ & $1 / T O$ & 0 & 1 \\
\hline Tr/r & $1 / 40$ & $\varphi / \Lambda$ & G/TO & 0 & r \\
\hline$I V / T$ & 1/qr & $9 / \pi T$ & $11 / \pi \Delta$ & 0 & $r$ \\
\hline $10 / 4$ & $r / T$ & $19 / 00$ & rI/TQ & 0 & 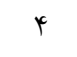 \\
\hline$q / 4 \varphi$ & $r / 90$ & $r N / r$ & $\Gamma_{1 / T \Delta}$ & 0 & 0 \\
\hline $99 / 4$ & •/Ar & o/Ar & $1 / T \Delta$ & ro & 9 \\
\hline rV/Or & I/VT & $\varphi / \Delta r$ & G/TO & $r_{0}$ & v \\
\hline$r Y / T r$ & $r / 4 q$ & N/VG & $11 / T \Delta$ & $r_{0}$ & $\wedge$ \\
\hline$I V / \Delta D$ & $r / N r$ & IV/OT & TI/TO & $r_{0}$ & 9 \\
\hline $10 / 1 r$ & $r / N \pi$ & rq/Or & $\Gamma_{1 / T \Delta}$ & $r_{0}$ & 10 \\
\hline$V I / r$ & $\circ / 19$ & o/rq & $1 / T O$ & $\omega_{0}$ & 11 \\
\hline$r q / r$ & $r / 40$ & $\Gamma / \Lambda$ & G/TO & ఎ. & Ir \\
\hline$r N / \Delta$ & $r / \pi r$ & 9/9T & $11 / T \Delta$ & $\omega_{0}$ & ir \\
\hline$r q / 9$ & G/TA & $1 \% / 9 V$ & TI/TO & Q. & 14 \\
\hline$r y / Q$ & $\mathrm{~V} / \mathrm{Vq}$ & $r \mu / 49$ & rI/ro & Q. & 10 \\
\hline
\end{tabular}

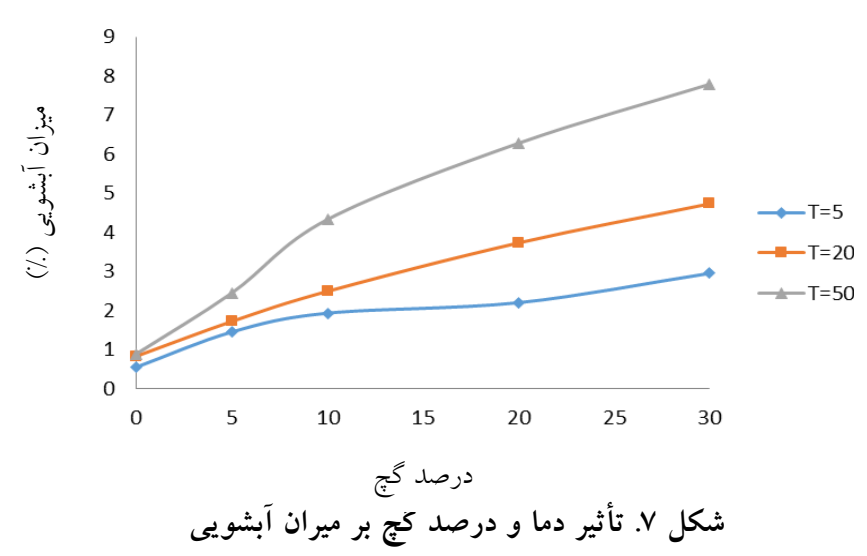

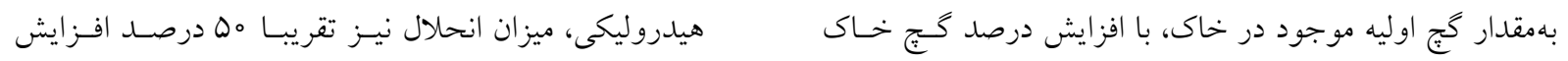

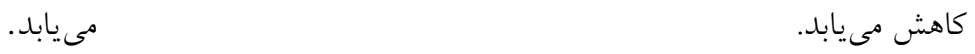

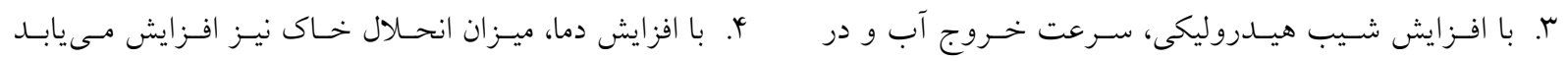

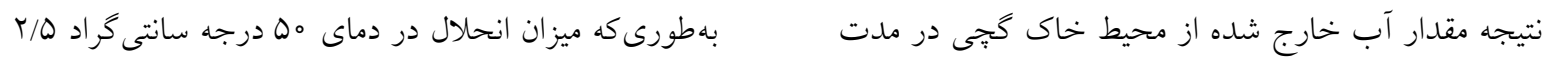

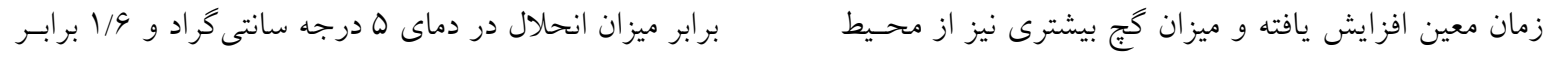

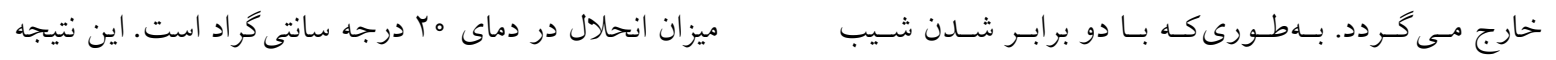




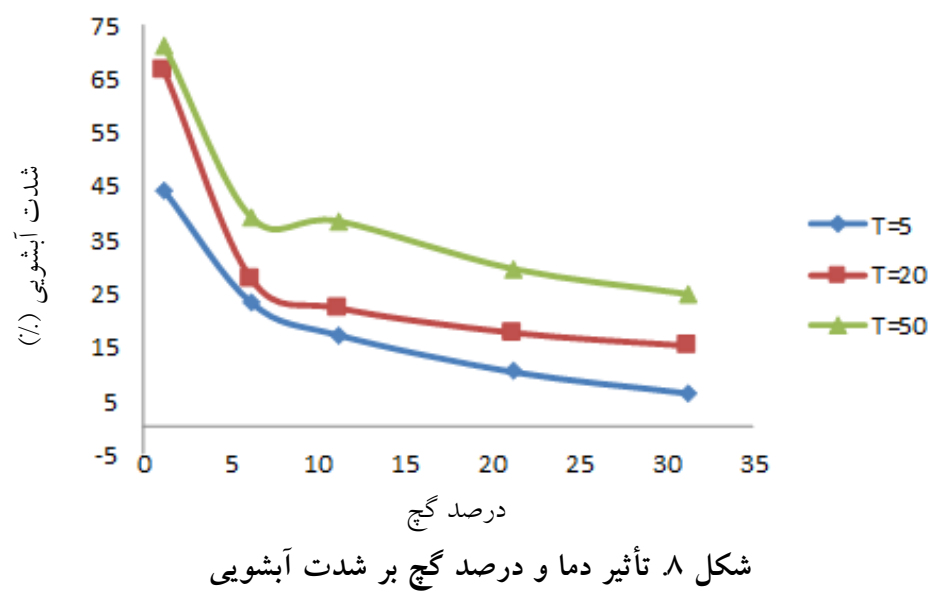

$$
\begin{aligned}
& \text { آزمايشگاه فنى و مكانيك خاك استان ايلام و شركت سازهآزماى } \\
& \text { با نتايج ساير محققين (0) نيز مطابقت دارد. }
\end{aligned}
$$

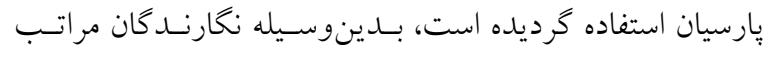

$$
\begin{aligned}
& \text { تقدير خود را از مديريت وكاركنان دستخاههاى ياد شــده اعـلام }
\end{aligned}
$$

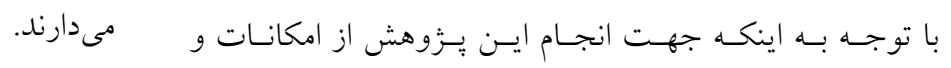

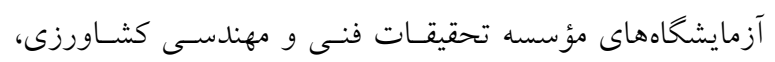

$$
\begin{aligned}
& \text { منابع مورد استفاده }
\end{aligned}
$$

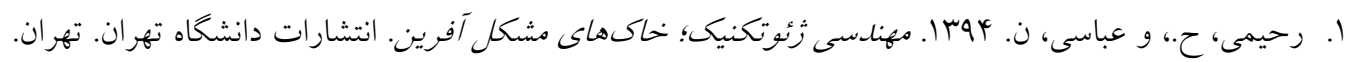

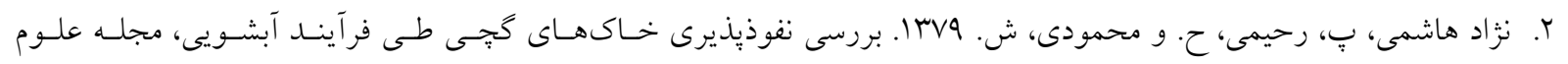

$$
\begin{aligned}
& \text { كشاورزى ايران ابr(Y): }
\end{aligned}
$$

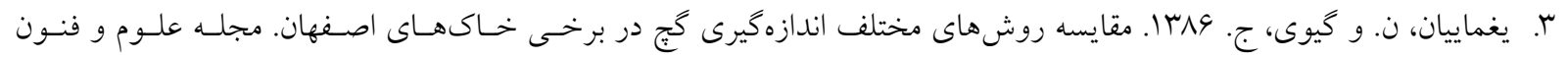

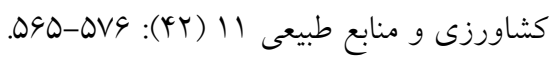

4. Abbasi, N., R. Bahramloo, M. Movahedan. 2015. Strategic planning for remediation and optimization of irrigation and drainage detworks: A case study for Iran. Agriculture and Agricultural Science Procedia, Elsevier, No. 4, pp: 211-221.

5. Abbaspoor, S., H. Daavi and J. Fili. 2008. Practical methods in improving constructed canals on gypsiferous soils in operating irrigation networks, Case study: Canal A, Behbahan Network”, In: Proceeding of the $1^{\text {st }}$ Iranian Seminar on Geotechnical Issues of Irrigation and Drainage Networks, Ag. Eng. Research Institute, Karaj, Iran.

6. Afsharian, A. A., N. Abbasi, A. Khosrojerdi, H. Sedghi. 2016. Analytical and laboratory Evaluation of the solubility of Gypsiferrous soils. Civil Eng. J. 2(11): 590-599.

7. Akpokodje Enuvie G. 1985. The engineering classification of some Australian arid zone soils. Bulletin of the International Association of Engineering Geology 31(1): 5-8.

8. Arakelyan, E. A. 1986. Characteristics and determination of the physical properties of gypsum soils. Soil Mechanics \& Foundation Eng. 23(1): 27-29.

9. Coutinet, S. 1965. Méthodesd'analyseutilisables pour les sols salés, calcaireset gypseux. Agronomic Tropical, Etudes Scientifiques 20(12): 1242-1253.

10. James, A. N. and R. R. Lupton. 1978. Gypsum and anhydrite in foundation of hydraulic structures, Geotechnique 28(3): 249-272. 
11. Mahmoodi, SH. 1994. Properties and management of gypsiferous soils. PP: 29- 31. In: Proceeding of the $4^{\text {th }}$ Soil Science Congress of Iran, Isfahan Univ. of Technology.

12. Movahedan, M., N. Abbasi and M. Keramati. 2012. Wind erosion control of soils using polymeric materials. Eurasian J. of Soil Sci. 1(2) $81-86$.

13. Petrokhin, V. P. 1993. On the Problem of Construction on Saline Soils, Balkema Publishing Co.

14. Rahimi, H., S. Tatlari and P. Nejadhashemi. 1997. Evaluation of some physical and chemical properties of gypsiferous soils. Iranian J. of Agric. Sci. 29(1): 117-129

15. Rahimi, H. and P. Nejadhashemi. 1999. Effect of leaching on consolidation properties of gypsiferous soils. Iranian J. of Agric. Sci. 30(2): 241-254

16. Rahimi, H. and A. Yoosefi. 1995. Failure of underground water storage at Hengam Island due to being founded on salt Dome, Technical Report, Hormozgan Regional Water Board, Iran.

17. Rahimi H., N. Abbasi, H. Shantia. 2011. Application of geomembrane to control piping of sandy soil under concrete canal lining (A case study: Moghan irrigation project, Iran), J. of Irrigation and Drainage, ICID, 60: 330337

18. Rahimi H. and N. Abbasi. 2008. Failure of concrete canal lining on fine sandy soils (A case study for Saveh project), Journal of Irrigation and Drainage, ICID. 57: 83-92.

19. Sadrekarimi, J., M. Kiyani and B. Fakhri. 2006. Gypsum Dissolution Effects on the Performance of a Large Dam, ICOLD, Barcelona, Spain. 


\title{
The Effects of Some Peripheral Conditions on the Solubility of Gypiferous Soils
}

\author{
Nader Abbasi ${ }^{1 *}$ and Ali Abbas Afsharian²
}

(Received: Aug. 3-2016; Accepted: Sept. 16-2017)

\begin{abstract}
Gypsiferous soils are one of the problematic soils which, due to solubility and contact with water, are a threat to various civil structures, especially water structures. Various factors affect the rate and amount of gypsum particles solubility. Gypsum types, the soil texture, the amount of gypsum in soil, the hydraulic gradient, and temperature and flowing water from gypsum soil are the major factors affecting the quality and quantity of the gypsum solution. In this research, the effects of some peripheral conditions including water temperature and hydraulic gradient on the solubility of gypsum soils were studied. To this aim, samples of gypsum soils were provided artificially by adding various rates of the natural gypsum rock including 0, 5, 10, 20 and 30 percent by weight of clay soil. Then, all gypsum soils were leached under five hydraulic gradients levels including 0.5, 1, 2, 5 and 10. The results indicated that the rate of Gypsum in the soil had a direct effect on the rate of solution in a way that by increasing the percent of Gypsum, the rate of solubility was increased. Also, the rate of leaching (the rate of the derived Gypsum from soil to the primary rate of Gypsum) was decreased by increasing the rate of Gypsum. In addition, by increasing hydraulic gradient, the speed of water and its amount in soil environment within a specified time were raised; further the rate of gypsum was increased too. Also, it was found that the rate of the solubility was increased directly by the temperature. The solubility rate of the gypsum soil at $50 \mathrm{C}^{0}$ was found to be 2.5 and 1.6 times greater than that of the soil at 5 and $20 \mathrm{C}^{0}$, respectively.
\end{abstract}

Keywords: Gypsiferous soil, solubility rate, hydraulic gradient, temperature.

1. Agric. Eng. Res. Institute, Agric. Res., Education and Extension Organiz., AREEO, Karaj, Iran.

2. Ilam Regional Water Authority, Ilam, Iran.

*: Corresponding Author, Email: nader_iaeri@yahoo.com 